\title{
Serum leptin levels in children and adolescents with insulin-dependent diabetes mellitus in relation to metabolic control and body mass index
}

\author{
W Kiess ${ }^{1}$, M Anil $^{1}$, W F Blum ${ }^{1,2}$, P Englaro ${ }^{1,3}$, A Juul ${ }^{4}$, A Attanasio ${ }^{2}$, J Dötsch ${ }^{1}$ and W Rascher ${ }^{1}$ \\ ${ }^{1}$ Children's Hospital, Justus Liebig University, Feulgenstr. 12, D-35385 Giessen, Germany, ${ }^{2}$ Lilly Germany, Saalburgstr. 153 , \\ D-61350 Bad Homburg, Germany, ${ }^{3}$ Instituto di Semeiotica Medica, Via Ospedale Civile 105, University of Padova, I-35123 Padova, Italy \\ and ${ }^{4}$ Rikshospitalet, Department of Growth and Reproduction, 9 Blegdamsvej, DK-2100 Copenhagen, Denmark \\ (Correspondence should be addressed to W Kiess, Children's Hospital, University of Leipzig, Oststr. 21-25, D-04317 Leipzig, Germany)
}

\begin{abstract}
The $o b$ protein, termed leptin, is produced by adipocytes and is thought to act as an afferent satiety signal regulating weight through suppressing appetite and stimulating energy expenditure in humans and/or rodents. Insulin has been found to be a potent stimulator of leptin expression in rodents. It is unclear at present whether this insulin action is a direct or an indirect effect. To investigate whether leptin concentrations in children and adolescents with type 1 diabetes (IDDM) were related to metabolic status, body weight, body mass index and insulin treatment, we have measured leptin concentrations in serum from 13 newly diagnosed IDDM patients before the beginning of insulin treatment ( 8 girls, 5 boys, aged 4.7-17.5 years) and in 134 patients with IDDM during treatment ( 64 girls, 70 boys, aged 2.6-20.1 years) using a specific radioimmunoassay. The data from patients with diabetes were compared with normative data that were derived from a large cohort of healthy children and adolescents. Serum from children with newly diagnosed diabetes had significantly lower levels of leptin (mean $1.28 \pm 1.60 \mathrm{ng} / \mathrm{ml}$, range $0.14-6.13 \mathrm{ng} / \mathrm{ml}$ ) compared with healthy children $(n=710)$ (mean $2.2 \mathrm{ng} / \mathrm{ml}$, range $0.26-14.4 \mathrm{ng} / \mathrm{ml}$ ) and compared with insulin-treated children and adolescents (mean $5.18 \pm 5.48 \mathrm{ng} / \mathrm{ml}$, range $0.26-29.77 \mathrm{ng} / \mathrm{ml})(P<0.0001)$ even after adjustment for gender and body mass index (BMI). Serum leptin levels in patients with IDDM were significantly correlated with BMI $(r=0.42, P<0.0001)$. Multiple regression analysis showed that age and BMI were significantly correlated with leptin levels, while duration of diabetes, mean $\mathrm{HbA}_{1 \mathrm{c}}$ levels, insulin dose and plasma glucose, triglyceride and cholesterol levels were not. Females had higher serum leptin concentrations than males even when adjusted for BMI $(P<0.0001)$. Surprisingly and most importantly, leptin levels in insulin-treated young adult (Tanner stage 5) patients were significantly higher than values found in the healthy nondiabetic reference population when adjusted for sex, Tanner stage and BMI.

These findings suggest that leptin levels in IDDM patients show a similar dependency on adipose tissue and age as in healthy, normal children. The data provide evidence that insulin may be of importance as a regulator of serum leptin levels in vivo not only in rodents but also in humans. It is hypothesized that the elevated BMI-adjusted leptin levels in adolescents with IDDM could indicate either that these patients may be oversubstituted by the intensified insulin therapy that they are receiving or that their body composition and body fat content may differ from that of healthy adolescents in the sense that they have a relative increase in fat mass.
\end{abstract}

European Journal of Endocrinology 138 501-509

\section{Introduction}

The recent isolation and characterization of the obese $(o b)$ gene and its gene product, leptin, will help us to understand better the molecular pathogenesis of obesity and weight homeostasis (1-4). Leptin is a 167 amino acid polypeptide with a molecular size of $16 \mathrm{kDa}$ that is synthesized in adipose tissue. Leptin is thought to signal satiety and filling of peripheral fat stores to the brain, acting through specific receptors in the hypothalamus.
Thus, leptin may play a crucial role in metabolic homeostasis by reducing feeding behavior and food intake and increasing energy expenditure (3-8).

Leptin serum concentrations and $o b$ gene expression are increased in human obesity and in various animal models of obesity. In fact, there is a strong positive correlation between serum leptin concentrations and body mass index (BMI) and body fat content (9-11). In addition, leptin production by adipose tissue seems to be under neuroendocrine control. In humans and animals, 
factors involved in glucose metabolism, such as glucose itself, insulin, glucocorticoids and a variety of cytokines have been found to be potent regulators of leptin expression $(7,9,12,13)$. In vivo, insulin has a strong stimulatory effect on leptin in rodents $(7,14,15)$, while the data in humans are conflicting. Although some reports suggest that in humans insulin does not stimulate leptin production $(16,17)$, there is evidence from clinical $(9,18)$ and also from in vitro studies (19) that insulin does have a role in leptin regulation. Only sparse information is available to answer the question whether diabetes itself and/or metabolic control in patients with type 1 diabetes (IDDM) are related to serum leptin levels in such patients.

One of the well known side effects of intensified insulin treatment of adolescents and young adults with IDDM is its association with increased weight gain and development of obesity (20-22). Therefore, we have measured serum leptin concentrations in children and adolescents with IDDM at the onset of diabetes before initiation of insulin treatment and also during insulin therapy and compared these data with normative data from a large cohort of healthy children and adolescents. We have asked whether or not metabolic control, insulin treatment, BMI, sex, age and pubertal stage are related to serum leptin levels in young patients with IDDM.

\section{Subjects and methods Patients and control subjects}

We have studied 147 children und adolescents with IDDM ( 72 girls and 75 boys). Clinical and auxologic data from the patients were obtained during routine out-patient visits and recorded using a computerized standard data sheet. At the time of blood sampling 13 patients (untreated patients, 8 girls and 5 boys) had not yet received exogenous insulin therapy, since they had just been hospitalized with newly detected diabetes. The remaining 134 patients were under various insulin replacement treatment regimens at the time of blood sampling. Clinical and biochemical characteristics of the treated and untreated diabetic patients are shown in Table 1.

None of the patients had an acute or chronic illness apart from IDDM, none had high blood pressure or microalbuminuria and none had been taking medication other than insulin. None of the patients had given special attention to his/her diet apart from the usual diabetes-related nutrition recommendations. Of the 134 treated patients, 32 were receiving intensified insulin therapy ( 3 or 4 daily injections) and 102 were on more conventional insulin treatment (1 or 2 daily injections). Serum was obtained when venous blood was drawn for clinical reasons for the measurement of cholesterol, triglycerides and creatinine during routine visits in the afternoon. Sera were obtained by centrifugation at $4^{\circ} \mathrm{C}$, immediately frozen and stored at $-20^{\circ} \mathrm{C}$ until further analysis. The reference range of serum leptin levels was determined from 710 healthy children and adolescents (aged 5-20 years) from a large population study (23). Informed consent had been given by the patients and/or their families. The study was approved by the Ethics Committee of the Justus Liebig University of Giessen, Germany.

\section{Anthropometric measurements}

Weight and height (measured with a Harpenden stadiometer) were recorded in all patients. Measurements were expressed as S.D. score (SDS) for chronological age using the references from the Zurich longitudinal study (24). Pubertal stage, based on pubic hair and breast development, was assessed according to Tanner (25). Sixty-five of the diabetic subjects were prepubertal (Tanner stage 1), 40 were pubertal (Tanner stage 2-4) and 42 were postpubertal (Tanner stage 5$)$. BMI $\left(\mathrm{kg} / \mathrm{m}^{2}\right)$ was calculated for all patients and subjects.

\section{Laboratory measurements}

$\mathrm{HbA}_{1 \mathrm{c}}$ was determined from venous blood by a commercially available monoclonal antibody technique (DCA 2000, Ames, Bayer, Leverkusen, Germany) (normal range in non-diabetic healthy adults 4.56.1\%) (26). Blood glucose, cholesterol and triglyceride determinations were performed using a hexokinase method and an automated laboratory system (TDX) respectively.

\section{Leptin radioimmunoassay}

Leptin levels were measured with a specific radioimmunoassay (RIA) using human recombinant leptin for tracer and standard preparation (a kind gift from Dr Heiman, Lilly Research Laboratories, Indianapolis, IN, USA). Details of this RIA have been described elsewhere $(23,27)$. Sensitivity of the assay with undiluted samples was $0.03 \mathrm{ng} / \mathrm{ml}$. Coefficients of inter- and intra-assay variation were 8.5 and $0.8 \%$ respectively.

\section{Statistical analysis}

Statistical analysis was performed using the GraphPad Prism (GraphPad Software, San Diego, CA, USA) program. Data with Gaussian distribution were correlated by linear regression. Nonparametric data were compared by Mann-Whitney $\mathrm{U}$ test and parametric data were compared by two-tailed $t$-test. Results are expressed as means \pm s.D., median and range. Serum leptin and triglycerides concentrations were log normally distributed. Correlation coefficients were determined by linear regression analysis. Because of extreme 
Table 1 Clinical, auxologic and biochemical data of 13 children and adolescents with IDDM (8 females, 5 males) at clinical manifestation of diabetes (before initiation of insulin treatment) and of 134 children and adolescents with IDDM (64 females, 70 boys) during insulin treatment.

\begin{tabular}{|c|c|c|c|c|}
\hline & $n$ & Mean \pm S.D. & Median & Range \\
\hline \multicolumn{5}{|c|}{ Before initiation of insulin treatment } \\
\hline Age (years) & 13 & $9.8 \pm 3.7$ & 9.7 & $4.7-17.5$ \\
\hline SDS height & 13 & $0.6 \pm 1.0$ & 0.6 & $-1.2-(+) 3.0$ \\
\hline BMI $\left(\mathrm{kg} / \mathrm{m}^{2}\right)$ & 13 & $15.2 \pm 3.0$ & 14.6 & 8.7-20.1 \\
\hline $\mathrm{HbA}_{1 \mathrm{c}}$ levels (\%) & 13 & $10.0 \pm 1.9$ & 10.1 & $6.7-12.3$ \\
\hline Glucose (mg/dl) & 13 & $293 \pm 123$ & 270 & $101-548$ \\
\hline Cholesterol (mg/dl) & 11 & $198 \pm 57$ & 209 & $125-309$ \\
\hline Triglycerides (mg/dl) & 12 & $213 \pm 268$ & 100 & 46-1009 \\
\hline \multicolumn{5}{|l|}{ During insulin treatment } \\
\hline Age (years) & 134 & $12.4 \pm 3.9$ & 12.5 & $2.6-20.1$ \\
\hline SDS height & 132 & $0.1 \pm 1.0$ & 0.15 & $-2.2-2.9$ \\
\hline $\mathrm{BMI}\left(\mathrm{kg} / \mathrm{m}^{2}\right)$ & 132 & $19.6 \pm 3.5$ & 19.4 & $13.0-32.1$ \\
\hline Age at onset (years) & 133 & $7.3 \pm 3.4$ & 6.9 & $1.5-17.5$ \\
\hline Diabetes duration (years) & 133 & $5.0 \pm 3.8$ & 4.9 & $0.02-16.2$ \\
\hline $\mathrm{HbA}_{1 \mathrm{c}}$ levels (\%) & 133 & $7.4 \pm 1.3$ & 7.3 & $5.0-11.6$ \\
\hline Glucose (mg/dl) & 121 & $166 \pm 91$ & 156 & $43-429$ \\
\hline Cholesterol (mg/dl) & 125 & $169 \pm 41$ & 164 & $54-379$ \\
\hline Triglycerides (mg/dl) & 110 & $104 \pm 67$ & 86 & $37-443$ \\
\hline Insulin $(\mathrm{U} / \mathrm{kg})$ & 133 & $0.83 \pm 0.29$ & 0.81 & $0.2-1.8$ \\
\hline
\end{tabular}

values in the distribution of pubertal stages and insulin injection numbers per day, the comparisons between groups were evaluated by Spearman correlations using the SPSS (Software Package for the Social Sciences, USA) and the Prism (version 2.0, GraphPad Software) programs. Multiple regression analysis was used to examine the effect of multiple independent variables (e.g. age, BMI, $\mathrm{HbA}_{1 \mathrm{c}}$, duration of diabetes and insulin dose) on a single dependent variable (e.g. serum leptin concentration). All statistical tests were two-tailed and significance was defined at the $P<0.05$ level.

\section{Results}

\section{Clinical and auxologic data of children and adolescents with IDDM}

Clinical data of the children and adolescents with IDDM are summarized in Table 1. Height SDS, serum cholesterol and triglyceride concentrations were similiar in newly manifested and treated IDDM patients, while the groups differed significantly in respect to mean age, BMI, $\mathrm{HbA}_{1 \mathrm{c}}$, pubertal status, mean age at onset of diabetes and serum glucose. $\mathrm{HbA}_{1 \mathrm{c}}$ and glucose levels were significantly higher in newly manifested patients $(P<0.0001$ and $P<0.001$ respectively) whereas mean age, BMI, and pubertal stage were significantly lower compared with those receiving insulin treatment (mean age $P<0.05$, BMI $P<0.0001$, pubertal status $P<0.05)$. Mean age at onset of diabetes was higher in the group of untreated diabetic patients $(P<0.05)$.

\section{Serum leptin levels in children and adolescents with IDDM}

Table 2 summarizes the serum leptin levels of all subjects according to treatment and grouped according

Table 2 Leptin concentrations $(\mathrm{ng} / \mathrm{ml})$ in the serum of 13 children and adolescents with IDDM at clinical manifestation of diabetes (before initiation of insulin treatment) and in the serum of 134 children and adolescents with IDDM during insulin treatment as measured by a specific radioimmunoassay.

\begin{tabular}{lccc}
\hline & Mean \pm S.D. & Median & Range \\
\hline Before initiation of insulin treatment & & & \\
All $(n=13)$ & $1.28 \pm 1.60$ & 0.88 & $0.14-6.13$ \\
Females $(n=8)$ & $1.89 \pm 1.8^{*}$ & 1.35 & $0.52-6.13$ \\
Males $(n=5)$ & $0.29 \pm 0.15$ & 0.24 & $0.14-0.5$ \\
During insulin treatment & & & \\
All $(n=134)$ & $5.18 \pm 5.58$ & 2.77 & $0.26-29.77$ \\
Females $(n=64)$ & $7.49 \pm 6.45 \dagger$ & 5.67 & $0.86-29.77$ \\
Males $(n=70)$ & $3.07 \pm 3.24$ & 2.09 & $0.26-17.28$ \\
\hline
\end{tabular}

${ }^{*} P<0.01, \dagger P<0.0001$ compared with male subjects. 

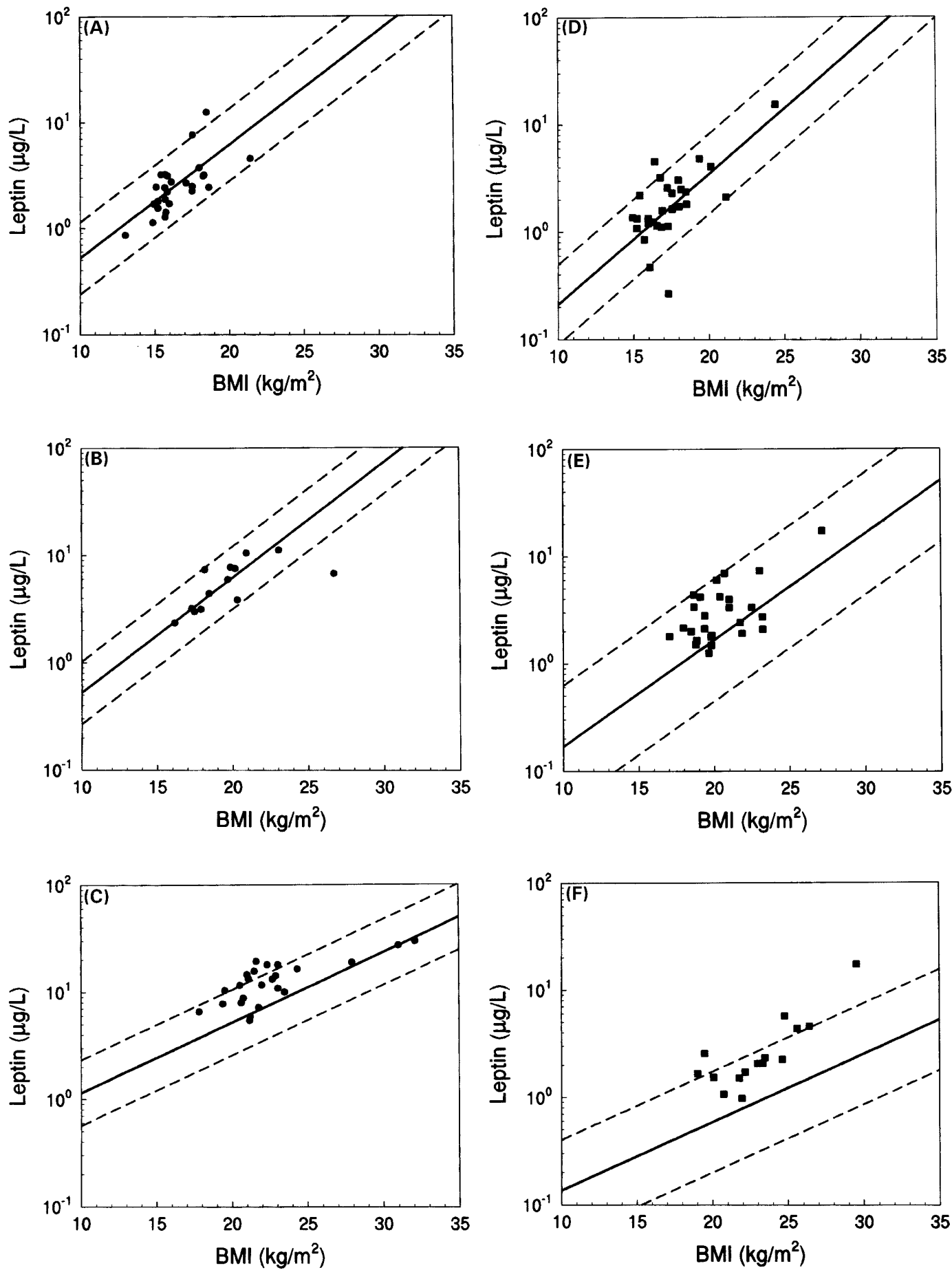

Figure 1 Serum concentrations of leptin versus BMI in treated female and male diabetic subjects. The lines indicate the 5th, 50th and 95 th percentiles of the reference control group. Symbols represent leptin values of individual IDDM patients. (A) Females at Tanner stage 1; (B) females at Tanner stages 2-4; (C) adolescent females at Tanner stage 5; (D) males at Tanner stage 1; (E) males at Tanner stages 2-4; (F) males at Tanner stage 5. 
Table 3 Leptin serum concentrations in patients with IDDM at manifestation before the initiation of insulin treatment are lower than in the normal reference population, while in treated adolescents with IDDM leptin levels are higher than in nondiabetic healthy subjects. Data are expressed as leptin S.D. score (SDS) based upon leptin serum levels from 710 healthy subjects matched for gender and pubertal stage.

\begin{tabular}{lllll}
\hline $\boldsymbol{n}$ & Pubertal stage & Insulin therapy & $\begin{array}{c}\text { SDS leptin } \\
\text { (mean } \pm \text { S.D. })\end{array}$ & $\boldsymbol{P}^{*}$ \\
\hline Females & & & & \\
8 & Tanner $1-5$ & No, before start & $-1.3 \pm 1.0$ & $<0.0001$ \\
26 & Tanner 1 & Yes & $-0.1 \pm 0.5$ & n.s. \\
14 & Tanner 2-4 & Yes & $-0.2 \pm 1.3$ & n.s. \\
24 & Tanner 5 & Yes & $+1.1 \pm 0.8$ & $<0.0001$ \\
Males & & & & 0.004 \\
5 & Tanner 1 & No, before start & $-1.3 \pm 1.0$ & n.s. \\
28 & Tanner 1 & Yes & $-0.1 \pm 0.7$ & 0.005 \\
26 & Tanner 2-4 & Yes & $+0.6 \pm 0.7$ & $<0.0001$ \\
16 & Tanner 5 & Yes & $+1.5 \pm 0.7$ & \\
\hline
\end{tabular}

${ }^{*} P$, the probability of a significant difference between the patients' cohorts and the corresponding reference groups. n.s., not significant.

to gender. There was a significant difference between the leptin levels of patients before initiation of insulin treatment and the levels in treated patients irrespective of whether or not patients were differentiated according to sex $(P<0.0001)$. More specifically, patients' serum leptin concentrations were analyzed based upon BMI, gender and pubertal stage. Figure 1 shows the distribution of the serum concentrations of leptin from insulin-treated female and male patients according to BMI within the 5th, 50th and 95th percentiles as grouped according to pubertal stage. Serum leptin concentrations were significantly higher in girls than in boys $(6.81 \pm 6.33 \mathrm{ng} / \mathrm{ml}$ vs $2.88 \pm 3.20 \mathrm{ng} / \mathrm{ml}, P<0.0001)$. Serum leptin concentrations in treated adult patients (Tanner stage 5) were significantly higher than those in the reference population when adjusted for sex, pubertal stage and BMI
(Table 3). Figure 2 shows the distribution of serum leptin concentrations from newly diagnosed female and male patients before initiation of insulin treatment according to BMI within the 5th, 50th and 95th percentiles.

\section{Relation between serum leptin concentrations and metabolic and clinical parameters in children and adolescents with IDDM}

Single correlations assessed by linear regression analysis between log leptin and clinical and biochemical parameters in all patients and in the treated diabetic patients alone are presented in Table 4 . In both groups, log leptin correlated significantly with age, BMI, pubertal status and the numbers of insulin injections per day. No significant correlation was found between
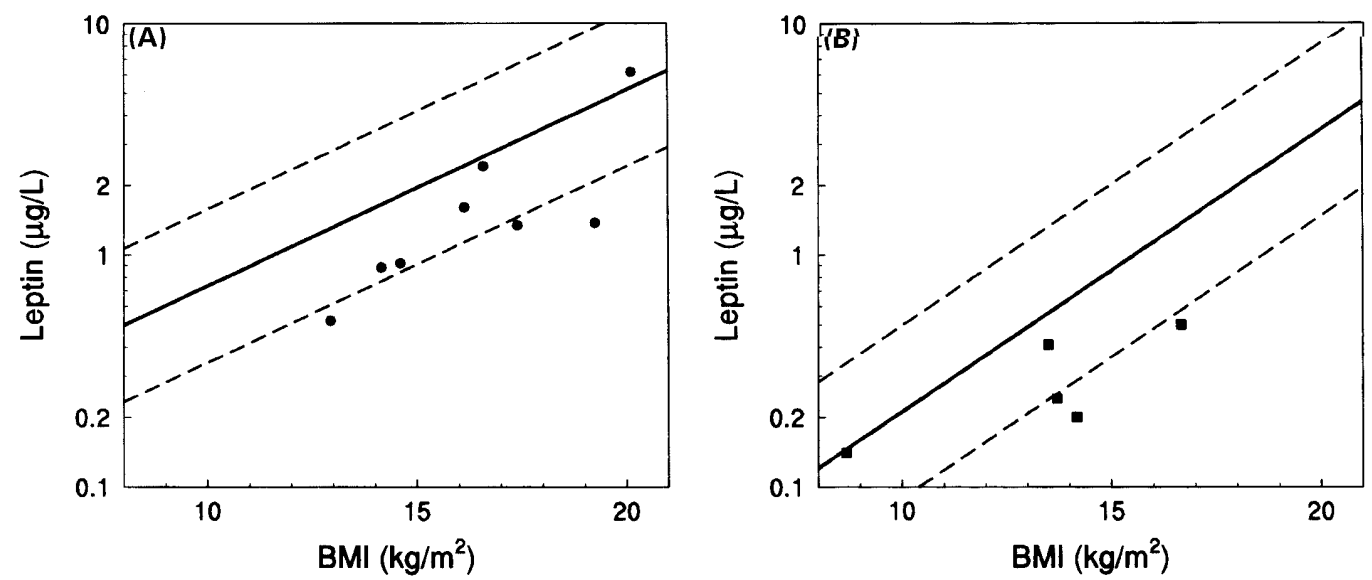

Figure 2 Serum concentrations of leptin versus BMI in untreated female and male diabetic subjects at the onset of diabetes before initiation of insulin treatment. The lines indicate the 5th, 50th and 95th percentiles of the reference non-diabetic control group. Symbols represent leptin values of individual IDDM patients. (A) Females at Tanner stage 1-5 $(n=8)$; (B) males at Tanner stage $1(n=5)$. 
Table 4 Correlations of log leptin to clinical and biochemical parameters in all patients and in insulin-treated diabetic patients.

\begin{tabular}{|c|c|c|c|c|c|c|}
\hline \multirow[b]{2}{*}{ Variable } & \multicolumn{3}{|c|}{ All patients } & \multicolumn{3}{|c|}{ Treated patients } \\
\hline & $n$ & $r$ & $P$ & $n$ & $r$ & $P$ \\
\hline Height SDS & 147 & 0.00 & n.s. & 132 & 0.03 & n.s. \\
\hline $\mathrm{BMI}\left(\mathrm{kg} / \mathrm{m}^{2}\right)$ & 147 & 0.49 & $<0.0001$ & 132 & 0.40 & $<0.0001$ \\
\hline Puberty & 147 & 0.48 & $<0.0001$ & 134 & 0.47 & $<0.0001$ \\
\hline $\mathrm{HbA}_{1 \mathrm{c}}(\%)$ & 146 & 0.00 & n.s. & 133 & 0.06 & n.s. \\
\hline Diabetes duration (years) & 147 & 0.11 & $<0.0001$ & 133 & 0.05 & n.s. \\
\hline Age at onset (years) & 147 & 0.04 & n.s. & 133 & 0.11 & n.s. \\
\hline Insulin $(\mathrm{U} / \mathrm{kg})$ & & & & 133 & 0.18 & $<0.001$ \\
\hline Injections per day & & & & 134 & 0.32 & $<0.0001$ \\
\hline Cholesterol (mg/dl) & 136 & 0.00 & n.s. & 125 & 0.03 & n.s. \\
\hline
\end{tabular}

n.s., not significant.

leptin levels and triglycerides in serum. In addition, log transformed concentrations of leptin correlated with SDS height, $\mathrm{HbA}_{1 \mathrm{c}}$ and cholesterol levels in the treated patients when linear regression analysis was performed. In the entire study population, BMI was positively correlated with age $(r=0.38, P<0.0001)$, duration of diabetes $(r=0.26, P<0.0001)$ and insulin dose per body weight $(r=0.13, P<0.0001)$, whereas we found no significant relation between $\mathrm{BMI}$ and $\mathrm{HbA}_{1 \mathrm{c}}$, cholesterol and triglyceride plasma levels.

To investigate the effects of puberty on BMI and leptin levels in IDDM, female and male subjects were grouped according to pubertal stage, i.e. prepubertal (Tanner stage 1), pubertal (Tanner stage 2-4), and postpubertal (Tanner stage 5). BMI and leptin levels from prepubertal female subjects $(n=14)$ were significantly lower than those of pubertal females $(n=26)$ (BMI $16.4 \pm 2.0 \mathrm{~kg} / \mathrm{m}^{2}$ vs $18.8 \pm 3.0 \mathrm{~kg} / \mathrm{m}^{2}$, leptin $2.8 \pm$ $2.3 \mathrm{ng} / \mathrm{ml}$ vs $4.77 \pm 2.88 \mathrm{ng} / \mathrm{ml}, \quad P<0.05)$. Female adolescents $(n=32)$ (Tanner stage 5$)$ had even higher BMI and serum leptin levels than pubertal girls (BMI $22.4 \pm 3.4 \mathrm{~kg} / \mathrm{m}^{2}$, leptin $12.64 \pm 6.8 \mathrm{ng} / \mathrm{ml}$, $P<0.001)$. Male prepubertal subjects $(n=33)$ also had significantly lower BMI and leptin levels compared with pubertal male subjects $(n=26)(\mathrm{BMI}$ $16.8 \pm 2.6 \mathrm{~kg} / \mathrm{m}^{2}$ vs $20.5 \pm 2.1 \mathrm{~kg} / \mathrm{m}^{2}, \quad P<0,0001$, leptin $\quad 2.11 \pm 2.67 \mathrm{ng} / \mathrm{ml}$ vs $\quad 3.6 \pm 3.22 \mathrm{ng} / \mathrm{ml}$, $P<0.001)$. In males, leptin levels did not differ between pubertal and postpubertal subjects $(n=16,3.6 \pm$ $3.22 \mathrm{ng} / \mathrm{ml}$ vs $3.31 \pm 3.95 \mathrm{ng} / \mathrm{ml}$, not significant), although BMI was higher in postpubertal subjects than in pubertal boys $\left(23.6 \pm 2.9 \mathrm{~kg} / \mathrm{m}^{2}\right.$ vs $20.5 \pm$ 2.1, $P<0.05)$.

Serum log levels of leptin and BMI were significantly correlated in girls $(r=0.72, P<0.0001)$ and in boys $(r=0.51, P<0.0001)$.

Multivariate regression models were used in order to analyze the contribution of independent variables (age, BMI, duration of diabetes, $\mathrm{HbA}_{1 \mathrm{c}}$ and insulin dose) to the variation in serum leptin concentrations. The results of these analyses are shown in Table 5. The relations between leptin and BMI and age, already observed in the univariate regression model, were confirmed in the multiple regression analysis. In contrast, duration of diabetes, $\mathrm{HbA}_{1 \mathrm{c}}$ and insulin dose were not related to leptin in IDDM patients when analyzed by multivariate regression models (Table 5).

Table 5 Correlations between logarithmically transformed serum leptin levels and clinical and biochemical parameters as evaluated by multiple regression analysis.

\begin{tabular}{|c|c|c|c|c|}
\hline \multirow[b]{2}{*}{ Variables } & \multicolumn{2}{|c|}{ All patients $(n=147)$} & \multicolumn{2}{|c|}{ Treated patients $(n=134)$} \\
\hline & $r$ & $P$ & $r$ & $P$ \\
\hline Age (years) & 0.43 & 0.0001 & 0.45 & $<0.0001$ \\
\hline $\mathrm{BMI}\left(\mathrm{kg} / \mathrm{m}^{2}\right)$ & 0.48 & $<0.0001$ & 0.42 & $<0.001$ \\
\hline Diabetes duration (years) & 0.28 & n.s. & 0.22 & n.s. \\
\hline $\mathrm{HbA}_{1 \mathrm{c}}(\%)$ & 0.04 & n.s. & 0.21 & n.s. \\
\hline Insulin (U/kg) & 0.23 & n.s. & 0.14 & n.s. \\
\hline
\end{tabular}

n.s., not significant. 


\section{Discussion}

Low leptin levels, even after adjustment for BMI, were present at clinical presentation of diabetes in a small cohort of children and adolescents with IDDM before insulin treatment was begun. There are several possible explanations for this finding. (i) Low leptin levels in patients with newly onset diabetes might be related directly to the absent or low insulin levels in these patients. In fact, data from animal experiments suggest that insulin directly induces leptin expression, pointing to insulin as an important regulator of leptin $(7,28-30)$. In addition, streptozotocin-treated diabetic mice have reduced leptin mRNA levels which are partially restored by insulin treatment (14). In humans, however, reports on the influence of insulin on leptin are conflicting. While in some studies in the human leptin levels were not influenced by hyperinsulinemia and meal-related increases in circulating insulin levels $(17,29,31)$, Malmstroem et al., by using hyperinsulinemic clamps have also shown that insulin significantly stimulated serum leptin concentrations in man (18). In a more recent paper it is stated that 'leptin levels were higher in IDDM subjects and remained unchanged during (acute) hyperinsulinemia' (32). The most direct proof, however, that insulin stimulates leptin expression and synthesis in humans stems from in vitro studies with differentiated human adipocytes (19). (ii) Alternatively, very high glucose concentrations in these children prior to blood sampling could also suppress leptin levels. However, data regarding a putative regulation of leptin expression by glucose are conflicting. In mice and humans $o b$ mRNA was inhibited by food restriction associated with glucopenia and was stimulated by injection of glucose in some $(33,34)$ but not in other (11) studies. We found no correlation between serum glucose and leptin concentrations in IDDM patients receiving insulin. (iii) Our patients with IDDM at the onset of diabetes before the initiation of insulin treatment had low BMI values that were also significantly lower than the BMI values in treated diabetic patients. Thus, a reduced body fat mass due to increased lipolysis following insulin deficiency might have resulted in reduced absolute leptin levels in these patients. However, when leptin levels were adjusted for BMI by calculating S.D. scores, they were still significantly lower than in healthy control children (Fig. 2). Moreover, assuming that the reduced weight of these patients was, in part, also due to dehydration, the calculation of BMI-related leptin SDS would over- rather than underestimate leptin values with respect to fat mass. These findings suggest, therefore, that insulin may indeed be an important regulator of leptin levels in man.

The major determinants of serum leptin levels in IDDM patients were BMI, sex, pubertal stage and, independent from pubertal stage, age. Females had significantly higher leptin levels than males. These data are consistent with results from previous studies which also showed that serum leptin concentrations are strongly correlated with BMI and age, both in healthy adults $(9,17,28,33,35,36)$ and in non-IDDM patients (33). When the female diabetic patients were grouped with regard to pubertal status, there was a progressive increase in both BMI and serum leptin levels with progress of puberty. This is in accordance with the recent report of Ma et al. in which they also found lower leptin levels in prepubertal girls than in lean adult women (35). In contrast, absolute leptin levels of males did not increase between pubertal and postpubertal stages despite the fact that BMI values also increased during puberty and early adulthood in the male patients. The most likely explanation for this discrepancy is that in females the increase in BMI during and after puberty is mainly associated with an increase in adipose tissue, whereas in males the increase in BMI is due to an increase in muscle mass. Besides this sex difference in body composition direct influences of sex steroids may be causative (23).

The question remains as to why BMI-adjusted leptin levels in post-pubertal patients were elevated. One of the well known side effects of intensified insulin treatment of adolescents and young adults with IDDM is weight gain and development of obesity (20), although a reduction in elevated BMI values has also been reported (21). High food intake in order to avoid recurrent hypoglycemic episodes $(22,37,38)$, and decreased lipolysis (39) have been proposed as possible causes of weight gain associated with insulin treatment of diabetes. It is unclear what role regulatory factors such as leptin might play in the development of obesity in IDDM patients (40). Using univariate regression analysis, we found that BMI increases with insulin dose and the number of insulin injections per day (data not shown). Also, and most importantly, in the present study we found that adolescents with IDDM have higher serum leptin concentrations compared with a healthy, sex- and age-matched reference population. There are several possible explanations for this finding. (i) It is conceivable that body composition of IDDM patients is altered with the progressive use of multiple insulin injections in late puberty shifting body composition towards increased body fat mass. This explanation represents the most simple model and should therefore be favored as long as there is no further evidence which might support the alternative explanations. (ii) Transient but chronically and repetitively occurring hyperinsulinemia might inadequately stimulate leptin expression. In fact, since exogenous insulin requirements increase during puberty due to reduced insulin sensitivity (38), higher insulin doses administered by the adolescent patients might lead to transient hyperinsulinemia and subsequent hyperleptinemia. In fact, in a recent study of a small group of adult patients with IDDM, leptin levels were found to be higher in IDDM subjects 
but remained unchanged during (acute) hyperinsulinemia (32).

In conclusion, these data provide evidence that insulin could be an important stimulator of leptin synthesis not only in rodents but also in humans. The diminished serum leptin concentrations in patients with newly discovered IDDM could be caused by insulin deficiency and/or increased lipolysis. Insulin replacement then restores leptin concentrations to normal levels in pre- and early pubertal patients. The elevated leptin levels found in late and post-puberty may be due to altered body composition in these patients. In these patients fat mass could be disproportionately increased. Alternatively, intensified insulin therapy could cause chronic hyperinsulinemia. Since these patients develop obesity despite relatively high leptin levels, the question remains whether insulin could also cause some kind of leptin insensitivity, possibly by directly stimulating neuropeptide $\mathrm{Y}$ expression in the hypothalamus $(41,42)$.

\section{Acknowledgements}

We wish to thank the children and their families for participating in this study. We also wish to thank the nurses, diabetes educationists and colleagues who participated in the care of the patients.

\section{References}

1 Zhang Y, Proenca R, Maffei M et al. Positional cloning of the mouse obese gene and its human homologue. Nature 1994372 425-432.

2 Masuzaki H, Ogawa Y, Isse $\mathrm{N}$ et al. Human obese gene expression. Diabetes 199544 855-858.

3 Campfield LA, Smith FJ, Guisez Y et al. Recombinant mouse ob protein: evidence for a peripheral signal linking adiposity and central neural networks. Science $1995269546-549$.

4 Halaas JL, Gajiwala KS, Maffei M et al. Weight-reducing effects of the plasma protein encoded by the obese gene. Science 1995269 543-546.

5 Lindpaintner K. Finding an obesity gene. A tale of mice and man. New England Journal of Medicine 1995332 679-680.

6 Lönqvist F, Arner P, Nordfors L \& Schalling M. Overexpression of the obese $(\mathrm{ob})$ gene in adipose tissue of human obese subjects. Nature Medicine 19951 950-953.

7 Saladin R, De Vos P, Guerre-Millo M et al. Transient increase in obese gene expression after food intake or insulin administration. Nature 1995377 527-529.

8 Pelleymounter MA, Cullen MJ, Baker MB et al. Effects of the obese gene product on body weight in ob/ob mice. Science 1995269 $540-543$.

9 Considine RV, Sinha MK, Heiman ML et al. Serum immunoreactive leptin concentrations in normal-weight and obese humans. New England Journal of Medicine 1996334 292-295.

10 Murakami T \& Shima K. Cloning of rat obese cDNA and its expression in obese rats. Biochemical and Biophysical Research Communications $1995209944-952$.

11 Funahashi T, Shimomura I, Hiraoka $\mathrm{H}$ et al. Enhanced expression of rat obese (ob) gene in adipose tissues of ventromedial hypothalamus (VMH)-lesioned rats. Biochemical and Biophysical Research Communications $1995211469-475$.

12 De Vos P, Saladin R, Auwerx J \& Staels B. Induction of ob gene expression by corticosteroids is accompanied by body weight loss and reduced food intake. Journal of Biological Chemistry 1995270 15958-15961.

13 Kolaczynski JW, Ohannesian JP, Considine RV, Marco CC \& Caro JF. Response of leptin to short-term and prolonged overfeeding in humans. Journal of Clinical Endocrinology and Metabolism 199681 4162-4165.

14 Mizuno TM, Bergen H, Funabashi T et al. Obese gene expression: reduction by fasting and stimulation by insulin and glucose in lean mice, and persistent elevation in acquired (diet-induced) and genetic (yellow agouti) obesity. Proceedings of the National Academy of Sciences of the USA 199693 3434-3438.

15 Rentsch J \& Chiesi M 1996 Regulation of ob gene mRNA levels in cultured adipocytes. FEBS Letters 1996379 55-59.

16 Nolan JJ, Olefsky JM, Nyce MR, Considine RV \& Caro JF. Effect of troglitazone on leptin production - studies in vitro and in human subjects. Diabetes 199645 1276-1278.

17 Dagogo-Jack S, Fanelli C, Paramore D, Brothers J \& Landt M. Plasma leptin and insulin relationships in obese and non obese humans. Diabetes 199645 695-698.

18 Malmstroem R, Taskinen MR, Karonen F \& Jaervinen HY. Insulin increases plasma leptin concentrations in normal subjects and patients with NIDDM. Diabetologia 199639 993-996.

19 Wabitsch M, Jensen PB, Blum WF, Christofferson CT, Englaro P, Heinze E, Rascher W, Teller W, Tornquist H \& Hauner H. Insulin and cortisol promote leptin production in cultured human fat cells. Diabetes 199645 1435-1438.

20 Holl RW, Heinze E, Seifert M, Grabert M \& Teller WM. Longitudinal analysis of somatic development in paediatric patients with IDDM: genetic influences on height and weight. Diabetologia 199437 925-929.

21 Pietiläinen KH, Virtanen SM, Rissanen A, Rita H \& Mäenpää J. Diet, obesity, and metabolic control in girls with insulindependent diabetes mellitus. Archives of Diseases in Childhood 199573 398-402.

22 Abusrewil SS \& Savage DCL. Obesity and diabetic control. Archives of Diseases in Childhood 198464 1313-1315.

23 Blum WF, Englaro P, Hanitsch S, Juul A, Hertel TN, Skakkebaek NE, Birkett M, Heiman M, Attanasion A, Kiess W \& Rascher W. Serum leptin levels in healthy children and adolescents: dependence on body mass index, body fat mass, gender and developmental stage. Journal of Clinical Endocrinology and Metabolism 199782 2904-2910.

24 Prader A, Largo AH, Molinari L \& Issler RH. Physical growth in Swiss children from birth to 20 years of age. Helvetica Paediatrica Acta 198952 (Suppl) 1.

25 Tanner JM. Growth and Adolescence, edn 2. Oxford: Blackwell Scientific, 1962.

26 Kiess W, Past R, Meiler B, Kessler U, Strasser-Vogel B \& Landgraf R. Immediate $\mathrm{HbA}_{1 \mathrm{c}}$ measurements in the paediatric diabetes clinic: reliability, limitations and practical evaluation. Hormone and Metabolic Research 199426 351-352.

27 Schubring C, Kiess W, Englaro P, Rascher W, Dötsch J, Hanitsch S, Attanasio A \& Blum WF. Levels of leptin in maternal serum, amniotic fluid, and arterial and venous cord blood: relation to neonatal and placental weight. Journal of Clinical Endocrinology and Metabolism 199782 1480-1483.

28 Cusin I, Sainsbury A, Doyle P, Rohner-Jeanrenaud F \& Jeanrenaud B. The ob gene and insulin. A relationship leading to clues to the understanding of obesity. Diabetes 199644 1467-1470.

29 MacDougald AO, Hwang CS, Fan H \& Lane MD. Regulated expression of the obese gene product (leptin) in white adipose tissue and 3T3-L1 adipocytes. Proceedings of the National Academy of Sciences of the USA $1995929034-9037$.

30 Leroy P, Dessolin S, Villageois P, Moon BC, Friedman JM, Ailhaud G \& Dani C. Expression of ob gene in adipose cells: regulation by insulin. Journal of Biological Chemistry 1996271 2365-2368.

31 Kolaczynski JW, Nyce MR, Considine RV, Boden G, Nolan JJ, Henry R, Mudaliar SR, Olefsky J \& Caro JF. Acute and chronic effect of insulin on leptin production in humans: studies in vivo and in vitro. Diabetes $199645699-701$. 
32 Tuominen JA, Ebeling P, Stenman U-H, Heiman ML, Stephens TW \& Koivisto VA. Leptin synthesis is resistant to acute effects of insulin in insulin-dependent diabetes mellitus patients. Journal of Clinical Endocrinology and Metabolism 199782 381-382.

33 Sinha MK, Ohannesian JP, Heiman ML et al. Nocturnal rise of leptin in lean, obese, and non-insulin-dependent diabetes mellitus subjects. Journal of Clinical Investigation 199697 1344-1347.

34 Ostlund RE, Yang JW, Klein S \& Gingerich R. Relation between plasma leptin concentration and body fat, gender, diet, age, and metabolic covariates. Journal of Clinical Endocrinology and Metabolism 199681 3909-3913.

35 Ma Z, Gingerich RL, Santiago JV, Klein S, Smith CH \& Landt M. Radioimmunoassay of leptin in human plasma. Clinical Chemistry $199642942-946$.

36 Maffei M, Halaas J, Ravussin E, Pratley RE, Lee GH, Zhang Y, Fei H, Kim S, Lallone R, Ranganathan S, Kern PA \& Friedman JM. Leptin levels in human and rodent: measurement of plasma leptin and ob RNA in obese and weight-reduced subjects. Nature Medicine 19951 1155-1161.

37 Virtanen SM. Metabolic control and diet in Finnish diabetic adolescents. Acta Paediatrica 199281 239-243.
38 Zachrisson I, Wallensteen M \& Dahlquist G. Determinants of blood glucose variability in adolescents with insulin-dependent diabetes mellitus. Acta Paediatrica 199584 70-74.

39 Laakso M \& Pyörälä K. Adverse effects of obesity on lipid and lipoprotein levels in insulin-dependent and non-insulin-dependent diabetes. Metabolism 199039 117-122.

40 Rohner-Jeanrenaud F \& Jeanrenaud B. Obesity, leptin, and the brain. New England Journal of Medicine 1996334 324-325.

41 Wilding JPH, Gilbey SG, Bailey CJ, Batt RAL, Williams G, Ghatei MA \& Bloom SR. Increased NPY mRNA and decreased neurotensin mRNA in the hypothalamus of the obese (ob/ob) mouse. Endocrinology 1993132 1939-1944.

42 Schwartz MW, Baskin DG, Bukowski TR, Kuijper JL, Foster D, Lasser G, Prunkard DE, Porte D, Woods SC, Seeley RJ \& Weigle DS. Specificity of leptin action on elevated blood glucose levels and hypothalamic neuropeptide $\mathrm{Y}$ gene expression in ob/ob mice. Diabetes 199645 531-535.

Received 26 August 1997

Accepted 5 January 1998 